\title{
Estimating stand biomass in the Tamaulipan thornscrub of northeastern Mexico
}

\author{
José Návar ${ }^{\mathrm{a}^{*}}$, Eduardo Méndez ${ }^{\mathrm{a}}$ and Virginia Dale \\ ${ }^{a}$ Facultad de Ciencias Forestales, UANL, Km 145 Carretera Nacional Linares, N.L. 67700, Mexico \\ ${ }^{\mathrm{b}}$ Environmental Science Division, Oak Ridge National Laboratory, Oak Ridge, TN, USA
}

(Received 28 January 2002; accepted 27 June 2002)

\begin{abstract}
This paper presents information on below and aboveground standing biomass measurements and estimates using quadrat attributes in the Tamaulipan thornscrub of northeastern Mexico. Biomass components (i.e., leaves, branches, stem, and roots) were measured in 55 (5 $\mathrm{m} \times$ $5 \mathrm{~m}$ ) quadrats across northeastern Mexico. Total aboveground standing biomass was estimated on a per ha basis using six equations from two additive procedures, and contrasted against two conventional sets of equations. The results indicated that total standing weighted biomass averages $60.31 \pm 12.24 \mathrm{Mg} \mathrm{ha}^{-1}$, composed of leaf $\left(2.51 \pm 0.47 \mathrm{Mg} \mathrm{ha}^{-1}\right)$, branch $\left(24.44 \pm 4.88 \mathrm{Mg} \mathrm{ha}^{-1}\right)$, stem $\left(9.80 \pm 2.62 \mathrm{Mg} \mathrm{ha}^{-1}\right)$, and root $\left(23.56 \pm 4.25 \mathrm{Mg} \mathrm{ha}^{-1}\right)$ biomass. The additive equations developed in seemingly unrelated linear regression that use quadrat attributes provided unbiased biomass estimates within the range of precision reported by conventional procedures. The additive equations are recommended for use in estimating total stand biomass for several land management issues.
\end{abstract}

seemingly unrelated linear regressions

Résumé - Estimation de la biomasse sur pied de buissons épineux dans la région de Tamaulipan au nord-est du Mexique. Cet article présente des informations provenant de mesures et d'estimations de biomasses aériennes et souterraines sur pied des buissons épineux de la région du Tamaulipan, au nord-est du Mexique. Les composantes de ces biomasses furent mesurées sur 55 placeaux carrés répartis dans le nord-est du Mexique. Au niveau de chaque placeau, la biomasse totale sur pied fut estimée au moyen de six équations basées sur deux procédures additives, comparées à deux autres ensembles conventionnels d'équations appliqués à toutes les espèces arbustives présentes sur les placeaux observés. Les résultats ont montré que la biomasse totale sur pied est en moyenne égale à $60,31 \pm 12,24 \mathrm{Mg} \mathrm{ha}^{-1}$, composée de la biomasse des feuilles $\left(2,51 \pm 0,47 \mathrm{Mg} \mathrm{ha}^{-1}\right)$, des branches $\left(24,44 \pm 4,88 \mathrm{Mg} \mathrm{ha}^{-1}\right)$, des tiges $\left(9,80 \pm 2,62 \mathrm{Mg} \mathrm{ha}^{-1}\right)$ et des racines $\left(23,56 \pm 4,25 \mathrm{Mg}^{-1}\right)$. Les équations additives ont été développées au moyen de la méthode des régressions linéaires paraissant non liées. Elles ont été établies sur les caractéristiques des placeaux et ont donné des estimations non biaisées dans l'intervalle de la précision estimée, basée sur des procédures conventionelles. Ces équations sont donc recommandées pour estimer la biomasse totale sur pied des placettes dans différents cadres d'aménagement.

régressions linéaires apparemment non liées

\section{INTRODUCTION}

Accurate estimates of stand biomass are important for the balance of energy and elements such as carbon and nitrogen in forest ecosystems. The conventional procedure of estimating stand biomass uses allometric equations to predict individual tree biomass and sums these quantities to obtain total biomass per area [31]. Biomass prediction equations are built upon simple, inexpensive, and easily measured tree characteristics such as diameter at breast height (Dbh) or basal diameter (D), top height, canopy cover, or a combination thereof $[2,12,15,28,29,31]$. When quantifying aboveground biomass of forest ecosystems with multiple species, the use of allometric equations for each species becomes a tedious task and requires data on all species present. Therefore, single equations that use individual tree parameters have been developed for tropical forests [3], temperate forests of the eastern United States [20], and semi-arid subtropical shrubs of northeastern Mexico [29].

* Correspondence and reprints

Tel.: 821 24895; e-mail: jnavar@ccr.dsi.uanl.mx 
Foresters frequently inventory trees to report aboveground stand biomass based on allometric equations. This approach is currently a common practice around the world. For example, Brown et al. [3] and Fang et al. [11] used previously developed allometric equations of biomass measurements, coupled with conventional forest inventory data to quantify aboveground biomass of tropical and Chinese forests. Other procedures of stand biomass estimation use stand volume and weighted wood density parameters, but these estimates can be biased by a factor ranging from 0.3 [11] to 2.0 [19]. However, biomass equations that use stand attributes to inventory aboveground standing biomass are scarce. Fang et al. [11] reported stand biomass-volume relationships for Chinese forests and calculated the carbon stock in standing aboveground biomass.

Conventional techniques to predict biomass at the level of species or groups of species are classified as additive and non-additive equations, and they can be developed using stand or quadrat attributes as well. Clutter et al. [5] reported several non-additive techniques of allometric equations for single tree species. Cunnia and Brigs [7, 8] and Parresol [31] described three procedures of biomass estimation that meet the additivity requirements, where total biomass is estimated by (a) adding the best regressions for each biomass component, (b) using the same independent variables to estimate all biomass components, and (c) seemingly unrelated regression by setting constraints on the regression coefficients. The last procedure has been used extensively in the development of biomass tables for single species [7, 8, 14, 31]. The potential sources of error in using these procedures have been widely discussed [7, 29, 31]. Navar et al. [29] use these techniques for biomass estimation for single species and all species of the Tamaulipan thornscrub of northeastern Mexico. However, there is scarce information on the development of additive equations that predict aboveground biomass components using quadrat characteristics and how they compare with the conventional procedures of biomass inventory. In this paper we (i) develop equations that use quadrat parameters for biomass inventory and (ii) contrasted these equations that use quadrat attributes with (a) a single equation for each species that uses tree attributes and (b) a single equation for all species that uses tree attributes. The last two sets of equations were previously reported by Navar et al. [29].

\section{MATERIALS AND METHODS}

\subsection{Site description}

The Tamaulipan thornscrub covers approximately $200000 \mathrm{~km}^{2}$ in northeastern Mexico and Southern Texas $[10,13]$. In northeastern Mexico, it occurs in Coahuila (1 452800 ha), Nuevo Leon (900 $150 \mathrm{ha}$ ), and Tamaulipas (864 $500 \mathrm{ha}$ ), covering a total area of 3218800 ha [30] (figure 1). This ecosystem is limited to the northwest by the Chihuahuan Desert, to the west by the Sierra Madre Oriental mountain range, and to the south by the tropical rainforest of

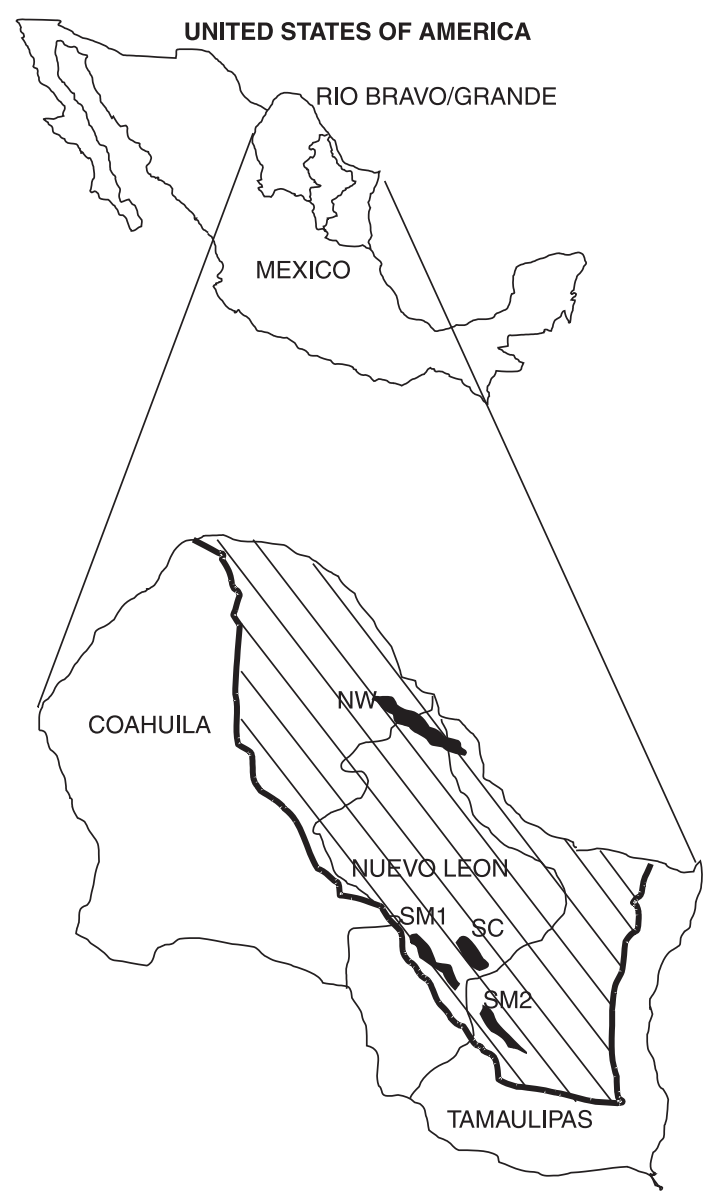

Figure 1. The distribution of the Tamaulipan thornscrub of northeastern Mexico and sampling locations (NW = northwestern; $\mathrm{SC}=$ south central; SM1 = Sierra Madre 1; and SM2 = Sierra Madre 2) in the Mexican States of Tamaulipas, Coahuila, and Nuevo Leon.

the Sierra Azul mountain range in south-central Tamaulipas. It has been extensively used as pastureland for the last 350 years [16] and is currently used for fuel, timber, food, and drugs [35].

The Tamaulipan thornscrub is quite dense and diverse, which makes it difficult to use a single biomass equation for all species in a stand. Romero [36] and Manzano and Návar [23] recorded on average 22 shrub species in 0.1 ha plots and more than 5000 shrubs per ha in 0.025 ha plots. Medium and small shrubs are common life forms, and tall individuals are disappearing because of land-use changes and selective harvesting for fuel wood and timber. The understory is composed of annual and perennial herbs and grasses, but it is inconspicuous under the high density canopy cover of shrubs. The dominant shrub species of this biome are reported in table I [6, 34].

The study area encompasses four locations within the Tamaulipan thornscrub ecosystem in the northeastern region of Mexico: (a) the northwestern portion, covering the northern part of the states of Coahuila, Nuevo Leon, and Tamaulipas (NW); (b) the south-central region of Nuevo Leon (SC); (c) the piedmont of the eastern Sierra Madre mountain range in the state of Nuevo Leon (SM1); and (d) the piedmont of the eastern Sierra Madre mountain range of western Tamaulipas (SM2). The southern part of the region 
Table I. Common shrub species of the Tamaulipan thornscrub of northeastern Mexico.

\begin{tabular}{ll}
\hline Common subtropical shrub species of southeastern Nuevo Leon \\
\hline Acacia berlandieri Benth. & Forestieria angustifolia Torr. \\
A. farnesiana (L.) Wild. & Fraxinus greggii A. Gray \\
A. rigidula Benth. & Gochnatia hypoleuca DC. \\
Calliandra conferta Gray & Helietta parvifolia (Gray) Benth. \\
Celtis pallida Torr. & Leucophyllum texanum (Teran \& Berl.) I.M. Johnst \\
Condalia hookeri M.C. Johnst. & Malpighi glabra L. \\
Cordia boissieri DC. & Mimosa biuncifera \\
Diospyros palmeri Scheele & Pithecellobium pallens (Benth.) Standtl. \\
Diospyros texana Scheele & Pithecellobium ebano (Berl.) Muller \\
Ehretia anacua (Terán \& Berl.) I.M. Johnst. & Prosopis laevigata (Willd.) M.C. Johnst. \\
Eysenhardtia polystachya (Ort.) Sarg. & Schaefferia cuneifolia Gray \\
Eysenhardtia texana Scheele & Zanthoxylum fagara (L.) Sarg. \\
\hline Common semiarid shrub species of northern Tamaulipas, Nuevo Leon, and Coahuila \\
\hline Acacia rigidula & Prosopis glandulosa \\
Porliera Angustifolia & Zizifus obtusifolia \\
\hline
\end{tabular}

is characterized by a moist, subtropical climate typical of southeastern Nuevo Leon and western Tamaulipas, while the northern bordering region is characterized by a semi-arid climate. Average annual precipitation is $400-500 \mathrm{~mm}$ in the northern part of the three-bordering Mexican states, $1000-1200 \mathrm{~mm}$ at the piedmont, and $1600 \mathrm{~mm}$ in the higher elevations of the first range of mountains of the Sierra Madre [24]. Convective storms are common. Most rainfalls are of short duration, high intensity, and small depth, and only storms of intensity $>20 \mathrm{~mm} \mathrm{~h}^{-1}$ are capable of producing surface runoff and soil erosion [27]. Cold front systems generate most of the winter rainfall, although accounts for less than $10 \%$ of the long-term annual average [26]. Pan evaporation is less variable than annual precipitation and approximates $2000 \mathrm{~mm}$ in the plains of the northern Gulf of Mexico [25].

Soils characterized as litosols and rendzins dominate the hilly slopes of the eastern Sierra Madre mountain range and the smaller mesetas on the plains of the northern Gulf of Mexico. Yermosols and xerosols are distributed most frequently in the arid western and northwestern region, and vertisols dominate the lowlands of the plains of the northern Gulf of Mexico.

The Tamaulipan thornscrub forests and its different low forest formations dominate land use, occupying $65 \%$ of the Rio San Juan Watershed, a basin located in northeastern Mexico, within the three bordering states. Shifting cultivation is common in the community-based land tenure system, ejido, which is rapidly reducing the area of the thornscrub forests. Other land cover includes coniferous and broadleaf forests, covering $6.37 \%$ of the total area; irrigated and dry land agriculture, covering $18 \%$ of the region; and reservoirs, urban area, grasslands, and secondary native scrub forests, which cover the remaining area [1].

\subsection{Data collection}

Within the study locations 55 quadrats, each $5 \mathrm{~m} \times 5 \mathrm{~m}$, were delineated. Quadrats were systematically placed at each location to represent all potential sources of variation in the physical characteristics of the environment. Quadrats were placed at least $10 \mathrm{~m}$ away from roads, and in areas representing typical environmental characteristics with the least disturbance by selective logging and grazing.
Eleven quadrats were located at NW, 14 at SC, 12 at SM1, and 18 at SM2. Prosopis glandulosa, a widely distributed species within the Chihuahuan Desert, dominates plant cover at NW. Cordia boissieri, Pithecellobium pallens, Pithecellobium ebano, and Acacia spp dominate plant cover at SC, SM1, and SM2. All woody shrubs were measured for basal diameter (d), top height (h), horizontal projection of canopy cover (ct), species (s), and biomass components (leaf, branch, stem). These data were collected within each quadrat. For the multi-stemmed species ( $P$. pallens, A. rigidula, and $B$. myricaefolia) only an average diameter and top height were recorded. Basal diameter, instead of diameter at breast height (Dbh) was measured to include all shrub size. Thus basal area was determined from basal diameter. Individual shrub canopy cover was estimated by measuring the four canopy radial sections of each shrub and calculating the circular area. These data provided information to estimate mean diameter (D), mean height (H), basal area (BA), species richness $(\mathrm{S})$, and density $(\mathrm{N})$ for each quadrat. In each quadrat, shrubs were felled and separated into leaves, branches, and main stem. For the multi-stemmed species, biomass components of all stems were measured, weighed fresh, and approximately $10 \%$ of each component was taken to the laboratory for ovendry analysis.

Root biomass contains a high proportion of forest biomass and methods to evaluate it vary greatly [39]. We used excavation methods conventionally applied in a random sample design to incorporate the large spatial variation associated with root distribution [18, 39]. The root biomass component was measured in three pits randomly placed within each of 34 selected quadrats of the SC, SM1, and SM2. Pits with dimensions of $1 \mathrm{~m} \times 1 \mathrm{~m} \times$ soil depth of the $\mathrm{A}$ and B horizons (approximately $0.50 \mathrm{~m}$ ) were excavated. All roots $>1 \mathrm{~cm}$ in diameter were isolated, weighed fresh, and oven-dried. In shallow soils, soil depth was excavated to less than $0.5 \mathrm{~m}$ because of the presence of the C-horizon. In addition, three soil samples of $1 \mathrm{~kg}$ were collected from each pit, air-dried, and pulverized, and fine roots were screened and isolated for ovendry weighting analysis. Biomass data were collected between January and July of 2001.

At the individual species scale, root biomass has been statistically related to tree characteristics [40]. In this study, root biomass was predicted by testing several relationships including the ratio of root/total aboveground biomass vs. average basal diameter, average 
top height, average canopy cover, and interactions of these variables. The statistical relationship developed for the first quadrats was used to estimate root biomass for the remaining 21 quadrats.

\subsection{Data analysis}

Estimates of total aboveground and root biomass were computed on per hectare basis for the distribution area of the Tamaulipan thornscrub. First an analysis of variance was conducted on the biomass component by using the locations as the main source of variation. Latter biomass estimates were weighted by assuming that the Tamaulipn thornscrub distributes $50 \%$ in the semiarid and $50 \%$ in the subtropical region of northeastern Mexico.

Two additive regression procedures were used for developing the quadrat biomass component equations based on average quadrat characteristics including average basal diameter $(\mathrm{cm})$, average top height $(\mathrm{m})$, basal area $\left(\mathrm{m}^{2} \mathrm{ha}^{-1}\right)$, stand density $\left(\mathrm{n} \mathrm{ha}^{-1}\right)$, species richness ( $\mathrm{n}$ in $5 \mathrm{~m} \times 5 \mathrm{~m}$ ), the combined variable $\mathrm{D}^{2} \mathrm{H}\left(\mathrm{cm}^{2} \mathrm{~m}^{-1}\right)$, and the logarithmic equivalents for each variable $\mathrm{LD}, \ldots, \mathrm{LD}^{2} \mathrm{H}$. In the first additive procedure, when developing regression relationships for each biomass component (leaf, branch, and stem at the quadrat scale) four different equations were tested: multiple linear (MSLin; equation (1)); multiple log-transformed (MSLog; equation (2)); linear covariance (CovLin; equation (3)); and log-transformed covariance (CovLog; equation (4)). Covariance analysis is a statistical procedure to estimate parameters of single equations for each biomass component. The quadrat attributes basal area, mean basal diameter, mean top height, stocking, species richness, and their log transformation are the covariables. The parameters of these equations were estimated in multiple linear regression using stepwise procedures. The stepwise procedure helps in the selection of appropriate independent variables. The first two regressions can be found in the literature of allometric equations for single tree species [5]. The last two equations have not been previously reported for single species neither at the stand scale, although Cunia and Briggs [9] tested a similar procedure called harmonization in a linear form for single species.

In the second additive procedure two regressions were tested: the seemingly unrelated linear regression procedure (SurLin), and the seemingly unrelated log-transformed regression (SurLog). Cunia and Briggs [7], Parresol [31], and Navar et al. [29] have discussed the advantages of the SurLin procedure for individual temperate forest species of eastern United States and subtropical shrubs of northeastern Mexico. The seemingly unrelated regressions were derived with the resulting independent variables of the MSLin and MSLog procedures, respectively. The constraints force the coefficients of each biomass components to be equal to the coefficients of total biomass. SurLin and SurLog methods were run in syslin procedures in SAS. In total, six different methods of estimating biomass components were tested. The Sur equations are not described below because they have similar independent variables to MSLin and MSLog. However, the coefficients are different because they were restricted to compute total biomass by adding the coefficients of similar independent variables.

$$
\begin{aligned}
& \hat{y}_{\text {leaf }}=\mathrm{b}_{10}+\mathrm{b}_{11}\left(\mathrm{D}^{2} \mathrm{H}\right)+\ldots+\mathrm{b}_{1 \mathrm{k}}(\mathrm{H})+\mathrm{b}_{12}\left(\mathrm{LD}^{2} \mathrm{H}\right)+\ldots+\mathrm{b}_{1 \mathrm{n}}(\mathrm{LH}) \\
& \hat{y}_{\text {branch }}=\mathrm{b}_{20}+\mathrm{b}_{21}\left(\mathrm{D}^{2} \mathrm{H}\right)+\ldots+\mathrm{b}_{2 \mathrm{k}}(\mathrm{H})+\mathrm{b}_{2 \mathrm{k}+1}\left(\mathrm{LDB}^{2} \mathrm{H}\right)+\ldots+\mathrm{b}_{2 \mathrm{n}}(\mathrm{LH}) \\
& \hat{y}_{\text {stem }}=\mathrm{b}_{30}+\mathrm{b}_{31}\left(\mathrm{D}^{2} \mathrm{H}\right)+\ldots+\mathrm{b}_{3 \mathrm{k}}(\mathrm{H})+\mathrm{b}_{3 \mathrm{k}+1}\left(\mathrm{LD}^{2} \mathrm{H}\right)+\ldots+\mathrm{b}_{3 \mathrm{n}}(\mathrm{LH}) \\
& \hat{y}_{\text {total }}=\hat{y}_{\text {leaf }}+\hat{y}_{\text {branch }}+\hat{y}_{\text {stem }} \\
& \hat{y}_{\text {leaf }}=\mathrm{b}_{10}+\mathrm{b}_{11}\left(\mathrm{D}^{2} \mathrm{H}\right)+\ldots+\mathrm{b}_{1 \mathrm{k}}(\mathrm{H})+\mathrm{b}_{12}\left(\mathrm{LD}^{2} \mathrm{H}\right)+\ldots+\mathrm{b}_{1 \mathrm{n}}(\mathrm{LH}) \\
& \hat{y}_{\text {branch }}=\mathrm{b}_{20}+\mathrm{b}_{21}\left(\mathrm{D}^{2} \mathrm{H}\right)+\ldots+\mathrm{b}_{2 \mathrm{k}}(\mathrm{H})+\mathrm{b}_{2 \mathrm{k}+1}\left(\mathrm{LDB}^{2} \mathrm{H}\right)+\ldots+\mathrm{b}_{2 \mathrm{n}}(\mathrm{LH})
\end{aligned}
$$

$$
\begin{aligned}
& L \hat{y}_{\text {stem }}=\mathrm{b}_{30}+\mathrm{b}_{31}\left(\mathrm{D}^{2} \mathrm{H}\right)+\ldots+\mathrm{b}_{3 \mathrm{k}}(\mathrm{H})+\mathrm{b}_{3 \mathrm{k}+1}\left(\mathrm{LD}^{2} \mathrm{H}\right)+\ldots+\mathrm{b}_{3 \mathrm{n}}(\mathrm{LH}) \\
& \hat{y}_{\text {total }}=\exp ^{L \hat{y}_{\text {leaf }}}+\exp ^{L \hat{y}_{\text {branch }}}+\exp ^{L \hat{y}_{\text {sem }}} \\
& \hat{y}_{\text {total }}=\mathrm{b}_{0}+\mathrm{b}_{11}\left(\mathrm{D}^{2} \mathrm{H}\right)+\ldots+\mathrm{b}_{1 \mathrm{k}}(\mathrm{H})+\mathrm{b}_{12}\left(\mathrm{LD}^{2} \mathrm{H}\right)+\ldots+\mathrm{b}_{1 \mathrm{n}}(\mathrm{LH})+(3) \\
& +b_{21}\left(D^{2} H\right)+\ldots+b_{2 k}(H)+b_{2 k+1}\left(L^{2} B^{2} H\right)+\ldots+b_{2 n}(L H)+ \\
& +b_{31}\left(D^{2} \mathrm{H}\right)+\ldots+b_{3 k}(H)+b_{3 k+1}\left(L^{2} H\right)+\ldots+b_{3 n}(L H) \\
& \text { L } \hat{y}_{\text {total }}=\mathrm{b}_{0}+\mathrm{b}_{11}\left(\mathrm{D}^{2} \mathrm{H}\right)+\ldots+\mathrm{b}_{1 \mathrm{k}}(\mathrm{H})+\mathrm{b}_{12}\left(\mathrm{LD}^{2} \mathrm{H}\right)+\ldots+\mathrm{b}_{1 \mathrm{n}}(\mathrm{LH})+(4) \\
& +b_{21}\left(D^{2} \mathrm{H}\right)+\ldots+b_{2 k}(H)+b_{2 k+1}\left(\text { LDB }^{2} H\right)+\ldots+b_{2 n}(L H)+ \\
& +b_{31}\left(D^{2} H\right)+\ldots+b_{3 k}(H)+b_{3 k+1}\left(L^{2} H\right)+\ldots+b_{3 n}(L H) \\
& \hat{y}_{\text {total }}=\exp ^{L \hat{y}_{\text {total }}}
\end{aligned}
$$

where $\hat{y}_{\text {leaf }}, \hat{y}_{\text {branch }}$, and $\hat{y}_{\text {stem }}=$ biomass component for leaf, branch, and stem in quadrats of $5 \times 5 \mathrm{~m}\left(\mathrm{Mg} \mathrm{ha}^{-1}\right), \mathrm{L} \hat{y}_{\text {leaf }}=$ natural logarithm of leaf biomass component, and $b_{i k}=$ statistical coefficients.

Comparisons between additive procedures (best regression equation and seemingly unrelated regression), among equations (six equations), and among scales (quadrat, 17 equations for each species, and one equation for all species present) were conducted. Comparisons between additive equations developed in this report were performed by contrasting estimated average goodness of fit statistics and predicted total quadrat biomass. Comparisons among equations developed at different scales were performed based on goodness of fit statistical averages across additive procedures, equations, and scales. Three scales were contrasted: (a) the additive equations developed in this report using quadrat attributes, (b) the additive equations developed for 17 single species using individual tree attributes, and (c) the additive equation developed for all species using individual tree attributes. The last two sets of equations were previously reported in a separate research paper [29], and they were applied to each shrub within each quadrat. The goodness-of-fit statistics used were the coefficient of determination, or fit index $\left(\mathrm{r}^{2}\right)$, standard error $(\mathrm{Sx})$, coefficient of variation $(\mathrm{CV})$, mean percent error $(\mathrm{S} \%)$, and percent error $(\mathrm{Pe})$. The Pe statistics is unusual and references can be found in Parresol [31]. These statistics were computed with observed and predicted total aboveground biomass as:

$$
\begin{gathered}
\mathrm{r}^{2}=1-(\mathrm{RSS} / \mathrm{TSS}) \quad \mathrm{RSS}=\sum_{\mathrm{i}=1}^{\mathrm{n}}\left(\mathrm{Y}_{\mathrm{i}}-\hat{\mathrm{Y}}_{\mathrm{i}}\right)^{2} \quad \mathrm{TSS}=\sum_{\mathrm{i}=1}^{\mathrm{n}}\left(\mathrm{Y}_{\mathrm{i}}-\overline{\mathrm{Y}}\right)^{2} \\
\overline{\mathrm{Y}}=\left[\sum_{\mathrm{i}=1}^{\mathrm{n}} \mathrm{y}_{\mathrm{i}}\right] / \mathrm{n} \\
\mathrm{Sx}=\sqrt{\mathrm{RSS} /(\mathrm{n}-\mathrm{p})} \\
\mathrm{CV}=(\mathrm{Sx} / \overline{\mathrm{Y}}) \times 100 \\
\mathrm{~S}(\%)=\frac{100}{\mathrm{n}} \sum_{\mathrm{i}=1}^{\mathrm{n}}\left|\mathrm{Y}_{\mathrm{i}}-\hat{\mathrm{Y}}_{\mathrm{i}}\right| / \hat{\mathrm{Y}}_{\mathrm{i}} \\
\mathrm{Pe}=\left[\frac{(196)^{2}}{\chi^{2}(\mathrm{n}-\mathrm{p})} \sum_{\mathrm{i}=1}^{\mathrm{n}}\left\{\frac{\hat{\mathrm{Y}}_{\mathrm{i}}}{\mathrm{Y}_{\mathrm{i}}}-1\right\}^{2}\right]^{1 / 2} \chi_{(\mathrm{v})}^{2}=0.853+\mathrm{v}+1.645(2 \mathrm{v}-1)^{1 / 2}
\end{gathered}
$$

where: $\mathrm{n}=$ number of observations, $\hat{\mathrm{Y}} \mathrm{i}=$ estimated total biomass in quadrat $\mathrm{i}\left(\mathrm{Mg} \mathrm{ha}^{-1}\right), \mathrm{Yi}=$ observed total biomass in quadrat $\mathrm{i}$ $\left(\mathrm{Mg} \mathrm{ha}^{-1}\right), \mathrm{p}=$ number of statistical coefficients to be estimated, $\mathrm{v}=\mathrm{n}-\mathrm{p}-1$.

These statistics were computed only for total biomass, rather than for each biomass component separately. Parresol [31] and Cunia and Briggs [8] suggested a correction factor when using log transformations of biomass data. In this report, we did not use a correction factor, because when variables were log-transformed, parameters were estimated with the log-transformation procedure and then converted to obtain the original total biomass units. Finally the 
statistics were estimated with the observed and estimated total biomass for each quadrat in conventional units. Least squares techniques in multiple regression, multiple regression with dummy variables, and system of linear equation procedures was used to compute parameters. The additive system of equations estimates total aboveground biomass by calculating each biomass component (leaf, branch, and stem). Root biomass is independently estimated because it was better related to total aboveground biomass rather than to the quadrat attributes.

Comparisons between additive procedures, equations, and scales were conducted by assessing the efficiency in estimating total quadrat biomass. Therefore, efficiency was estimated as (xi-xb)/xb, where $\mathrm{xi}=$ goodness of fit statistic $\mathrm{i}$ and $\mathrm{xb}=$ best goodness of fit statistic. Additive biomass equations (procedure 1 and 2 described earlier) were worked in four (MSLog, MSLin, CovLog, and CovLin) and two (SurLog and SurLin) different forms. Therefore, averages were estimated for goodness-of-fit statistics and total quadrat biomass.

\section{RESULTS AND DISCUSSION}

A total of 30 woody species were observed in all 55 quadrats. The highest importance values (iv) (relative dominance + relative frequency + relative abundance) were recorded for Cordia boissieri (iv = 48), Pithecellobium pallens (iv = 44), Prosopis glandulosa (iv = 30), Acacia berlandieri (iv = 27), and Diospyros texana (iv $=27$ ). At the semiarid location, $P$. glandulosa, $P$. angustifolia, and $A$. rigidula recorded the highest importance values. At the subtropical locations, C. boissieri, P. pallens, G. hypoleuca, H. parvifolia, and A. rigidula dominated the plant community. At the SM locations, D. texana, A. berlandieri, P. pallens, C. boissieri, $A$. wrightii, A. rigidula, and $G$. hypoleuca dominated the plant community. High stem density characterizes the Tamaulipan thornscrub, with an average slightly greater than 5000 stems ha $^{-1}$ (table II). This system is composed of shrubs or small trees with average diameter and top height of $6.5 \mathrm{~cm}$ and $3.2 \mathrm{~m}$, respectively. These attributes result in a mean basal area of $16.9 \mathrm{~m}^{2} \mathrm{ha}^{-1}$. Although canopy cover of average shrubs is large $\left(3.4 \mathrm{~m}^{2} \mathrm{shrub}^{-1}\right)$ and stand cover exceeds $17500 \mathrm{~m}^{2} \mathrm{ha}^{-1}$, shrubs are inconspicuous due to the widespread distribution of tree branches. In some places, canopy cover strongly overlaps between shrubs. Thus, this plant community is characterized by high canopy overlap in some places and by open spaces within and between shrubs in other areas.

\subsection{Measured aboveground biomass components}

Observed aboveground biomass components are statistically different among locations $(P=0.0077)$. Total aboveground biomass $\left(30.16 \pm 5.66 \mathrm{Mg} \mathrm{ha}^{-1}\right)$ was smaller in the NW semiarid location than the subtropical SC $\left(50.89 \pm 10.84 \mathrm{Mg} \mathrm{ha}^{-1}\right)$, and SM2 (48.29 $\left.\pm 4.67 \mathrm{Mg} \mathrm{ha}^{-1}\right)$ locations. Total aboveground biomass was not statistically different between the SM1 location $\left(44.03 \pm 10.33 \mathrm{Mg} \mathrm{ha}^{-1}\right)$ and the NW location, between SM1 and SM2, nor between SM1 and SC locations. Assuming that the semiarid and subtropical Tamaulipan thornscrub distributes equally, 50\% of the total area each, of the three Mexican States (3 $217450 \mathrm{ha}$ ), average weighted total aboveground biomass is $38.94 \pm 7.14 \mathrm{Mg} \mathrm{ha}^{-1}$. Navar et al. [28] estimated from 0.25 ha plots an average aboveground biomass of $51 \mathrm{Mg} \mathrm{ha}^{-1}$. Heiseke and Foroughbakhch [17] reported for the Tamaulipan thornscrub between 34.21 and $62.70 \mathrm{Mg} \mathrm{ha}^{-1}$ in the plains and between 26.06 and $37.70 \mathrm{Mg} \mathrm{ha}^{-1}$ in the hills. Heiseke [16] concluded that this biome has a maximum standing biomass of $50 \mathrm{Mg} \mathrm{ha}^{-1}$. Carstens [4] measured between 35 and $47 \mathrm{Mg} \mathrm{ha}^{-1}$ considering only shrubs and trees of this plant community. Therefore, our measurements are consistent with other estimates in the Tamaulipan thornscrub of south central Nuevo Leon.

\subsection{Measured root biomass}

Root biomass was linearly related to total aboveground standing biomass for all 34 measured quadrats (figure 2). The relationship that includes average top height, average horizontal canopy cover, and total aboveground biomass provided better goodness-of-fit statistics. However, this multiple regression equation was not used to predict the missing root biomass measurements of the remaining 21 quadrats. The former equation is more sensitive to total aboveground root biomass. The simple linear regression equation determined that total aboveground standing biomass explained $63 \%$ of the total root biomass variation. The procedure used to measure and estimate root biomass result in large errors $(\mathrm{Sx}=$ $5.4 \mathrm{Mg} \mathrm{ha}^{-1}$ or $\mathrm{CV}=18.6 \%$ ) because of the spatial variation of this plant component [37]. Difference in root distribution between the 30 species observed in all 55 quadrats may explain much of the variation in root biomass. The ratio of root to total aboveground biomass was $40.2 \%$. The ratio of root to branch biomass was $96.0 \%$, and the linear regression

Table II. Characteristics of shrub species in 55 quadrats of the Tamaulipan thornscrub forest of northeastern Mexico.

\begin{tabular}{|c|c|c|c|c|c|}
\hline \multirow[t]{2}{*}{ Statistic } & \multirow{2}{*}{$\begin{array}{c}\text { Density } \\
\left(\mathrm{No} \mathrm{ha}^{-1}\right)\end{array}$} & \multirow{2}{*}{$\begin{array}{c}\text { Basal Area } \\
\left(\mathrm{m}^{2} \mathrm{ha}^{-1}\right)\end{array}$} & Basal Diameter (cm) & Top Height (m) & Canopy Cover $\left(\mathrm{m}^{2}\right)$ \\
\hline & & & Mean & Mean & Mean \\
\hline Mean & 5140 & 16.90 & 6.47 & 3.24 & 3.42 \\
\hline Std Dev & 2008 & 0.33 & 1.46 & 0.88 & 1.75 \\
\hline C.I. $\left(_{1-\alpha=0.95}\right)$ & \pm 532 & \pm 0.01 & \pm 0.39 & \pm 0.23 & \pm 0.46 \\
\hline
\end{tabular}

Std Dev $=$ Standard Deviation, C.I. $=$ Confidence Intervals. 


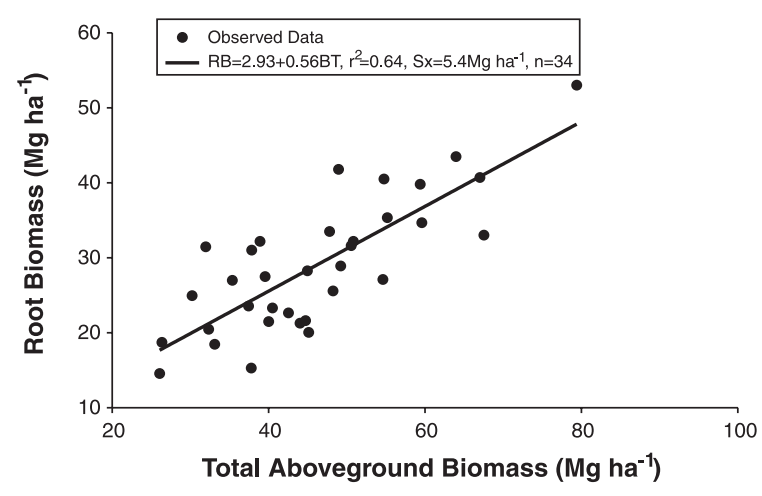

Figure 2. The relationship between stand root and total stand aboveground biomass for 34 quadrats located across the Tamaulipan thornscrub of northeastern Mexico.

between these two components had a slope coefficient of 0.81 indicating an equilibrium between these two biomass compartments. The ratio of root/shoot recorded in this study is larger than the $18-30 \%$ estimated for trees of temperate ecosystems $[18,21,33]$ and smaller than the ratio of $300 \%$ recorded for Mediterranean shrub species [38].

Estimates of root biomass at the ecosystem scale do not incorporate the variance due to regression. Therefore, the standard deviation and confidence intervals are larger than reported here. Using the measured and predicted biomass for the remaining 21 quadrats, average root biomass was statistically different among locations $(P=0.014)$. The NW location had smaller root biomass $\left(19.82 \pm 3.72 \mathrm{Mg} \mathrm{ha}^{-1}\right)$ than the SC location $\left(32.48 \pm 6.80 \mathrm{Mg} \mathrm{ha}^{-1}\right)$. The other two locations had similar root biomass $\left(\mathrm{SM} 1=27.91 \pm 6.25 \mathrm{Mg} \mathrm{ha}^{-1}\right.$ and $\mathrm{SM} 2=29.02 \pm 2.95 \mathrm{Mg} \mathrm{ha}^{-1}$ ) than the NW and SC locations. Weighted root biomass by distribution area of the subtropical and semiarid Tamulipan thornscrub is $23.56 \pm 4.25 \mathrm{Mg} \mathrm{ha}^{-1}$. Using the weighted biomass averages by area of distribution of the Tamaulipan thornscrub, root biomass represented 39\% of the total biomass measured. Branches composed $40 \%$, leaves $4 \%$, and stems only $16 \%$ of the total biomass. Thus, total standing biomass ranged from 59.83 in the NW to $83.37 \mathrm{Mg} \mathrm{ha}^{-1}$ in the SC location, with a weighted average of $60.31 \pm 12.24 \mathrm{Mg} \mathrm{ha}^{-1}$. Therefore, biomass carbon averages $30.15 \pm 6.12 \mathrm{Mg} \mathrm{ha}^{-1}$ by assuming a carbon/biomass factor of 0.50 [24]. Considering the total area covered by the Tamaulipan thornscrub of northeastern Mexico, total carbon stored in standing biomass in this plant community is $0.097 \pm 0.020$ Pg C. Because land-use change, mainly caused by shifting cultivation, has reduced dramatically the size of this ecosystem [22, 32, 37], a large amount of carbon has been released to the atmosphere from deforestation practices in this ecosystem. Quantification of this flux is important to climate change.

\subsection{Total biomass}

Observed and estimated total biomass for equations using stand attributes, shrub and species attributes, and shrub attributes are reported in table III. Average observed minus estimated biomass did not differ by more than $17 \%$ $\left(7.82 \mathrm{Mg} \mathrm{ha}^{-1}\right)$ for any of the additive procedures used. Additive equations using stand attributes biased mean total biomass by an average $1.4 \%\left(0.63 \mathrm{Mg} \mathrm{ha}^{-1}\right)$, equations for individual species biased mean total biomass on the average by $4.4 \%\left(1.98 \mathrm{Mg} \mathrm{ha}^{-1}\right)$, and equations for all species biased mean total biomass on the average by $8.1 \%\left(4.5 \mathrm{Mg} \mathrm{ha}^{-1}\right)$. For the equation with stand attributes, additive procedure Sur (2) had the least biased total biomass estimates $(0.5 \%)$ in contrast to procedure (1) (1.9\%). In particular the SurLin equation recorded the least bias $(0 \%)$. The linear equations (MSLin, CovLin, and SurLin) resulted in unbiased average biomass estimates unlike the $\log$ transformed equations (MSLog, CovLog, and SurLog) whose average biomass estimates were biased by less than $2.9 \%\left(1.3 \mathrm{Mg} \mathrm{ha}^{-1}\right)$ for all three types of equations.

Table III. Total aboveground biomass estimates for 56 quadrats using three regression approaches: (1) by using stand attributes, (2) by using single tree and species attributes, and (3) by using single tree attributes regardless of the species.

\begin{tabular}{lccc}
\hline \multirow{2}{*}{ Scale/Equation } & \multicolumn{3}{c}{ Statistical Parameters $\left(\mathrm{Mg} \mathrm{ha}^{-1}\right)$} \\
\cline { 2 - 4 } & Mean & Standard Deviation & Confidence Intervals $\left(_{1-\alpha=0.05}\right)$ \\
\hline 1/MSLog & $42.67^{\mathrm{a}}$ & 12.77 & \pm 3.38 \\
1/MSLin & $44.40^{\mathrm{a}}$ & 13.03 & \pm 3.44 \\
1/CovLog & $42.78^{\mathrm{a}}$ & 13.18 & \pm 3.48 \\
1/CovLin & $44.40^{\mathrm{a}}$ & 12.83 & \pm 3.39 \\
1/SurLog & $43.95^{\mathrm{a}}$ & 11.69 & \pm 3.09 \\
1/SurLin & $44.41^{\mathrm{a}}$ & 12.92 & \pm 3.42 \\
2/MSLog & $39.29^{\mathrm{a}}$ & 15.31 & \pm 4.05 \\
2/MSLin & $43.46^{\mathrm{a}}$ & 15.72 & \pm 4.16 \\
2/CovLog & $42.56^{\mathrm{a}}$ & 14.13 & \pm 3.73 \\
2/CovLin & $43.53^{\mathrm{a}}$ & 15.73 & \pm 4.16 \\
2/SurLog & $42.77^{\mathrm{a}}$ & 13.10 & \pm 3.46 \\
2/SurLin & $42.93^{\mathrm{a}}$ & 15.49 & \pm 4.09 \\
3/MSLog & $36.58^{\mathrm{b}}$ & 12.32 & \pm 3.26 \\
3/MSLin & $42.52^{\mathrm{a}}$ & 14.20 & \pm 3.75 \\
3/CovLog & $37.37^{\mathrm{b}}$ & 13.68 & \pm 3.62 \\
3/CovLin & $42.56^{\mathrm{a}}$ & 14.13 & \pm 3.73 \\
3/SurLog & $45.54^{\mathrm{a}}$ & 15.07 & \pm 3.98 \\
3/SurLin & $42.52^{\mathrm{a}}$ & 14.19 & \pm 3.75 \\
\hline //Q & & &
\end{tabular}

$1 /=$ Quadrat attributes, $2 / 17$ = equations for each species, $3 /=$ one equation for all species, $\mathrm{Q}=$ quadrat, $\mathrm{O}=$ observed average biomass $\left(\mathrm{Mg} \mathrm{ha}^{-1}\right), \mathrm{A}=$ MSLog equation, $\mathrm{B}=$ MSLin equation, $\mathrm{C}=\mathrm{CovLog}$ equation, $\mathrm{D}=$ CovLin equation, $\mathrm{E}=$ SurLog equation, $\mathrm{F}=\mathrm{SurLin}$ equation, $\hat{y}=$ mean, $\alpha=$ error, $C I=$ Confidence Intervals $(\alpha=0.05)$. Means with the same letter are not statistically different $(\alpha=0.05)$. 
Table IV. Goodness of fit parameters for biomass estimates in 55 quadrats with equations for each species, groups of species, and all species in two additive procedures of five different forms.

\begin{tabular}{|c|c|c|c|c|c|c|c|c|c|c|c|c|c|c|c|c|c|c|}
\hline \multirow{3}{*}{ Statistic } & \multicolumn{18}{|c|}{ Additive Equations to Estimate Biomass Components } \\
\hline & \multicolumn{6}{|c|}{ Equation with Stand Attributes } & \multicolumn{6}{|c|}{17 Equations for each species } & \multicolumn{6}{|c|}{ One Equation for all shrub species } \\
\hline & A & $\mathrm{B}$ & $\mathrm{C}$ & $\mathrm{D}$ & $\mathrm{E}$ & $\mathrm{F}$ & A & $\mathrm{B}$ & $\mathrm{C}$ & $\mathrm{D}$ & $\mathrm{E}$ & $\mathrm{F}$ & A & $\mathrm{B}$ & $\mathrm{C}$ & $\mathrm{D}$ & $\mathrm{E}$ & $\mathrm{F}$ \\
\hline $\mathrm{Sx}$ & 12 & 12 & 12 & 11 & 12 & 12 & 10 & 7 & 11 & 7 & 14 & 7 & 14 & 11 & 13 & 11 & 14 & 11 \\
\hline $\mathrm{CV}$ & 27 & 27 & 27 & 25 & 28 & 27 & 22 & 16 & 25 & 16 & 31 & 16 & 31 & 25 & 29 & 25 & 32 & 25 \\
\hline
\end{tabular}

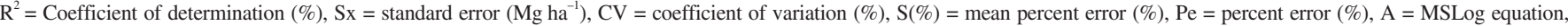
$\mathrm{B}=$ MSLin equation, $\mathrm{C}=$ CovLog equation, $\mathrm{D}=$ CovLin equation, $\mathrm{E}=$ SurLog equation, $\mathrm{F}=$ SurLin equation.

\subsection{Efficiency in biomass estimates when using equations with average stand attributes}

The goodness-of-fit statistics for three approaches of estimating aboveground stand biomass are reported in table $I V$. Equations, procedures, and scales recorded different coefficient values. Procedure (1) recorded the highest efficiency in total biomass estimates by $4 \%$. In particular, the average statistics varied by $3 \%, 2 \%, 4 \%, 1 \%$, and $8 \%$ for the $\mathrm{r}^{2}, \mathrm{Sx}, \mathrm{CV}$, $\mathrm{S}(\%)$, and $\mathrm{Pe}$ values, respectively. The linear covariance equation (CovLin) increased efficiency in total biomass estimates by $6 \%$ in contrast to the other equations tested. The $\mathrm{r}^{2}$ increased by $6 \%$, the Sx was reduced by $8 \%$, the CV was reduced by $7 \%$, the $\mathrm{S}(\%)$ was reduced by $1 \%$, and the Pe was reduced by $4 \%$ when using CovLin in contrast to the other additive equations. When contrasting all goodness of fit statistics, the CovLin equation increased efficiency by $7 \%, 5 \%$, $6 \%, 7 \%$, and 5\% in contrast to the MSLog, MSLin, CovLog, SurLog, and SurLin, respectively. The SurLin and MSLin had compatible goodness of fit statistics and ranked second in efficiency.

The efficiency increases by $19 \%$ when using 17 equations to predict total biomass at the stand scale in contrast to the other two scales $(16 \%$ when using equations at the stand scale, and $22 \%$ when using a single equation for all species). Using one allometric equation to predict quadrat biomass provides lower efficiency (10\%) than using one equation that uses per ha attributes. When contrasting these two last scales, the log-transformed equations (MSLog, CovLog, and SurLog) provided higher efficiencies $(25 \%)$ in the equation developed at the quadrat scale. On the other hand, the linear equations lost only $4 \%$ in efficiency in the equation that uses quadrat attributes in contrast to the equation that uses one single allometric equation. When contrasting equations among different scales, the SurLin equation had one of the highest efficiencies with compatible goodness of fit statistics in the equations developed with stand attributes and a single equation for all species. Consistently CovLin recorded slightly higher goodness of fit statistics in all three scales tested. The SurLin equation that uses 17 equations predicted total quadrat aboveground biomass with the largest efficiency. In general it increased efficiency estimates by $50 \%$ and $40 \%$ relative to the SurLin equations developed for quadrat attributes and for all species, respectively. The equation developed in this report that uses quadrat attributes slightly reduces efficiency in biomass estimates relative to the single SUR equation for all species by $6 \%$. That is, the equations that use stand attributes predicted aboveground biomass within the range of observed reliability by using the conventional procedures of biomass inventory.

Additive equations developed using quadrat attributes ease problems of statistical dependencies between biomass components because the coefficients of correlation between leaf and stem biomass were not statistically related $(\mathrm{r}=0.08$, $P=0.90)$. At the quadrat scale, the correlations between leaf and branch $(\mathrm{r}=0.52)$ and branch and stem $(\mathrm{r}=0.42)$ biomass were statistically significant, but the r-value decreased relative to the r-value developed for biomass components within (average r-values from each species) and across species (for all species).

The SUR procedures developed at the quadrat scale also meets the characteristics of biomass properties; i.e. total biomass is divided into smaller compartments (bolewood, root, leaf, etc.) and bolewood is divided into smaller compartments (bark, wood, branch, etc.). Therefore, the advantages of using additive equations fitted by SUR to estimate biomass components and total biomass include (a) prediction for the components sum to the prediction for the total quadrat, (b) the coefficients are more efficient, and (c) no single biomass compartment has values greater than the total biomass [7, 31]. In addition, there is an increasing need for estimating biomass compartments at the stand scale for environmental-related issues, productivity, and economic values. Several models, e.g., $\mathrm{CO}_{2}$ fix, requires estimates of the relative biomass proportions of leaves, branches, and stems. Natural resource managers require precise and consistent estimates of biomass components such as fuelwood, palatable biomass, pulp and paper biomass. The SUR equations developed at the quadrat scale for estimating each of the biomass components 
use only 14 parameters ( 2 for leaf, 8 for branch and 4 for stem). The SUR equation developed for all species uses 18 coefficients and the SUR equations for each species taken together use an average of 50 coefficients to estimate total biomass for each quadrat. An advantage of SUR is that it allows for the use of different component equation forms [31]. It is the most difficult additivity method to be calculated in this analysis, and predictions beyond the stand characteristics used to estimate parameters are uncertain [7], as is the case for any allometric equation.

The covariance regression equation, CovLin, applied in this research is an improvement of the harmonization procedure proposed by Cunia and Briggs [9]. This procedure uses a single best equation for each biomass component, all variables are statistically significant, and statistical coefficients behave harmoniously since they are estimated from the same pool of data. The disadvantages of this equation are that it does not account for dependencies of biomass components and that, for the smallest biomass components, it does not provide reliable estimates (i.e., leaf biomass).

The additive procedure (2), using the syslin procedure of parameter estimation in SAS is recommended to estimate biomass components and total biomass at the per ha scale for shrub species typical of the Tamaulipan thornscrub of northeastern Mexico. The SurLin equation that uses stand attributes on a per ha basis developed in this report included the independent variables stand density, $\mathrm{N}$, average top height, $\mathrm{H}$, species richness, $\mathrm{S}, \mathrm{D}^{2} \mathrm{H}$, and the log transformations of $\mathrm{D}^{2} \mathrm{H}, \mathrm{N}$, and basal area (BA). The SurLin equations that estimate per ha aerial biomass components are:

$$
\begin{aligned}
\mathrm{y}_{\text {leaf }}= & -3.39-0.3170 \mathrm{H}+0.00033 \mathrm{~N}-0.11290 \mathrm{~S} \\
& +1.2015 \ln \left(\mathrm{D}^{2} \mathrm{H}\right) \\
\mathrm{y}_{\text {branch }}= & 1.46+0.00403 \mathrm{~N}-1.39287 \mathrm{~S}+0.08707 \mathrm{D}^{2} \mathrm{H} \\
\mathrm{y}_{\text {stem }}= & 246.99+11.9170 \mathrm{H}-32.8904 \ln \left(\mathrm{D}^{2} \mathrm{H}\right)-25.2786 \ln (\mathrm{N}) \\
& +37.7530 \ln (\mathrm{BA}) .
\end{aligned}
$$

The summation of all components equals total aboveground biomass per ha, and the total aboveground biomass equation, derived from linear restrictions on the coefficients, can be expressed as:

$$
\begin{aligned}
\mathrm{y}_{\text {total }}= & 245.06+11.6 \mathrm{H}+0.00436 \mathrm{~N}-1.50577 \mathrm{~S} \\
& -31.6889 \ln \left(\mathrm{D}^{2} \mathrm{H}\right)+0.08707 \mathrm{D}^{2} \mathrm{H}-25.2786 \ln (\mathrm{N}) \\
& +37.7530 \ln (\mathrm{BA}) .
\end{aligned}
$$

The number of species can be considered a means of accounting for the diversity of life forms, wood densities, and other important aspects of productivity of the Tamaulipan thornscrub ecosystem. The equations provided here can be applied to quadrat characteristics expressed on a per area basis reported in table II. Should this set of equations be tested in quadrats of different shrub sizes or different quadrat scales, several sources of error must be considered. These potential sources are (a) the component due to the random selection of the sample unit and (b) the error of the biomass regression. Woods et al. [41] and Parresol [31] pointed out that the former is a function of the sampling design, the sample size, the type of estimator used, and the inherent variation between the sample units.

\section{CONCLUSIONS}

In this report, we observed that the equations developed using the seemingly unrelated linear regression procedure by employing quadrat attributes, predicts total biomass within the range of reliability of other conventional additive procedures developed for single shrub species. Therefore, this set of equations is recommended to estimate biomass components and total biomass on a per hectare basis. This information is critical for sustainable management of the Tamaulipan thornscrub of northeastern Mexico.

Acknowledgments: The CONACyT (Mexican Foundation for Science and Technology), IFS (International Foundation for Science) and PAICyT (UANL Fund for Science and Technology) partially funded this research through grants 28536-B, D/2535-1, and CT203- 99, respectively. Dr. Tristam West is recognized by his comments to improve the final manuscript. This report was written during a sabbatical leave at the Environmental Sciences Division of the Oak Ridge National Laboratory. Oak Ridge National Laboratory is managed by UT-Battelle, LLC, for the U.S. Department of Energy under contract DE-AC05-00OR22725.

\section{REFERENCES}

[1] Aranda R., Zamarripa R., Rojas L., Navarro J., Návar J., Ordenamiento hidrológico de la cuenca del río San Juan, in: Ninth US/Mexico Border States Conference on Recreation, Parks, Wildlife. USDA For. Ser. RMRS-P5. Tucson, Arizona, 1998.

[2] Brown S., Los bosques y el cambio climatico: el papel de los terrenos forestales como sumideros de carbono, in: Actas del XI Congreso Mundial Forestal: Recursos Forestales y Arboles. Vol 1. Antalya Turkia, October 13-22, 1997.

[3] Brown S., Gillespie A.J., Lugo A.E., Biomass estimation methods for tropical forests with aplications to forest inventory data, For. Sci. 35 (1989) 881-902.

[4] Carstens A., Gottinger Beitrage zur Land - und Forstwirtschaft in der Tropen and Subtropen. Heft 40. University of Gottingen. Gottingen, Germany, 1987.

[5] Clutter J.L., Forston J.C., Pienaar L.V., Brister G.H., Bailey R.L., Timber management: A quantitative approach, Wiley, New York, 1983, $333 \mathrm{p}$.

[6] Cotecoca-Sarh (Comisión Técnico Consultiva para la Determinación de los Coeficientes de Agostadero - Secretaría de Agricultura y Recursos Hidráulicos), 1973, Coeficientes de agostadero de la República Mexicana, Edo. de N. L. México. D.F.

[7] Cunia T., Briggs R.D., Forcing additivity of biomass tables - some empirical results, Can. J. For. Res. 14 (1984) 376-384.

[8] Cunia T., Briggs R.D., Forcing additivity of biomass tables - use of the generalized least-square method, Can. J. For. Res. 15 (1985) 23-28.

[9] Cunia T., Briggs R.D., Harmonizing biomass tables by generalized least squares, Can. J. For. Res. 15 (1985) 331-340.

[10] Diamond D., Riskind D., Orzell S., A framework for plant community classification and conservation in Texas at Dallas, Tex. J. Sci. 39 (1987) 203-221. 
[11] Fang J.Y., Wang G.G., Liu G.H., Xu S.L., Forest biomass of China: an estimate based on the biomass-volume relationship, Ecol. Appl. 8 (1998) 1084-1091.

[12] Frandsen W.H., Modelling big sagebrush as a fuell, J. Range Manage. 36 (1983) 596-600.

[13] González M., El límite sur de la Provincia Biótica Tamaulipeca. II Simposio Internacional sobre la Provincia Biótica Tamaulipeca UAT-UNAM, $1985,7 \mathrm{p}$.

[14] Green E.J., Reed D.D., Compatible tree volume and taper equations for pitch pine, North. J. Appl. For. 2 (1985) 14-16.

[15] Harniss R.O., Murray R.B., Reducing bias in dry leaf weight estimates of big sagebrush, J. Range Manage. 29 (1976) 430-432.

[16] Heiseke D., El matorral como recurso forestal. Reporte científico Número 1. Facultad de Ciencias Forestales UANL, Linares, N.L., Mexico, $1985,31 \mathrm{p}$.

[17] Heiseke D., Foroughbackch R., El matorral como recurso forestal. Reporte científico Número 1. Facultad de Ciencias Forestales UANL, Linares, N.L., Mexico, 1985, 31 p.

[18] Hoffmann C.W., Usoltsev V.A., Modelling root biomass distribution in Pinus sylvestris forests of the Turgai Depression of Kazakstan, For. Ecol. Manage. 149 (2001) 103-114.

[19] Houghton R.A., Tropical deforestation and carbon dioxide, Climate Change 19 (1991) 99-118.

[20] Jenkins J.C., Birdsey R.A., Pan Y., Biomass and NPP estimation for the mid-atlantic region (USA) using plot-level forest inventory data, Ecol. Appl. 11 (2001) 1174-1193.

[21] Laiho R., Laine J., Tree stand biomass and carbon content in an age sequence of drained pine mires in southern Finland, For. Ecol. Manage. 93 (1997) 161-169.

[22] Maldonado A., Desertificación en la subcuenca del Rio Limon, Linares, N.L. Tesis Profesional de Licenciatura. Facultad de Ciencias Forestales, UANL. Linares, N.L., Mexico, 1992.

[23] Manzano M.G., Návar J., Processes of desertification by goats overgrazing in the tamaulipan thornscrub (matorral) in north-eastern Mexico, J. Arid Environ. 44 (2000) 1-17.

[24] Mery G., Kanninen M., Las plantaciones forestales y el secuestro de carbono en Chile. Primer Congreso Latinoamericano IUFRO Valdivia Chile, 1998, 14 p.

[25] Návar J., Cavazos T., Domínguez P.A., Los balances hidrológicos mensuales con tres probabilidades de precipitación en el Estado de Nuevo León. Actas de la Facultad de Ciencias de la Tierra, NANL. Linares, N.L., México, 1994.

[26] Návar J., Agua y desarrollo sustentable en la cuenca baja de los ríos Bravo y San Juan, Ciencia UANL 2 (1999) 356-362.

[27] Návar J., Synnott T.J., Soil erosion and land use in northeastern Mexico, Terra 18 (2001) 247-253.
[28] Návar J., Nájera A., Jurado E., Dominguez P.A., Biomass estimation equations in the Tamaulipan thornscrub of northeastern Mexico, J. Arid Environ. (to appear).

[29] Návar J., Méndez E., Graciano J., Dale V., Parresol B., Biomass equations for shrub species of Tamaulipan thornscrub of northeastern Mexico, Can. J. For. Res. (to appear).

[30] Palacios-Prieto E., La condición actual de los recursos forestales en Mexico. Resultados del Inventarion Nacional Forestal 2000, Investigaciones Geograficas 43 (2000) 183-203.

[31] Parresol B., Assessing tree and stand biomass: a review with examples and critical comparisons, For. Sci. 45 (1999) 573-593.

[32] Proderleon, Promotora del Desarrollo Rural de Nuevo Leon. Estadisticas de cambio de uso de suelo 1980-1986. Gobierno del Estado de Nuevo Leon. Monterrey, N.L., Mexico, 1992.

[33] Ranger J., Gelhaye D., Belowground biomass and nutrient content in a 47-year-old Douglas-fir plantation, Ann. For. Sci. 58 (2001) 423-430.

[34] Reid N., Smith D.M.S., Marroquin J., Beyer-Munzel P., Floristic and structural variation in the Tamaulipan thornscrub, northeastern Mexico, J. Veg. Sci. 1 (1990) 529-538.

[35] Reid N., Marroquin J., Beyer-Munzel P., Utilization of shrubs and trees for browse, fuelwood and timber in the Tamaulipan thornscrub, northeastern México, For. Ecol. Manage. 36 (1990) 61-79.

[36] Romero F.G., Caracterización ecológica y definición de esquemas de muestreo en el matorral espinoso tamaulipeco del nordeste de México. Tesis Profesional de Maestría en Ciencias. Facultad de Ciencias Forestales, UANL, Linares, N.L., Mexico, 1999.

[37] Treviño E., Akca A., Návar J., Jimenez J., Aguirre O., Detection of land use change by satellite imagery in the municipality of Linares, Nuevo Leon, Mexico. Proceedings of the Fifth International Conference on Desert Development, August 12-17, 1996. Vol I. Texas Tech University, 1997.

[38] Vinas I.C.R., Ayanz A.S.M., Biomass of root and shoot systems of Quercus coccifera shrublands in eastern Spain, Ann. For. Sci. 57 (2000) 803-810.

[39] Vogt K.A, Vogt D.J., Bloomfield J., Analysis of some direct and indirect methods for estimating root biomass and production of forests at an ecosystem level, Plant Soil 200 (1998) 71-89.

[40] Wang J.R., Letchford T., Comeau P., Kimmins J.P., Above and below ground biomass and nutrient distribution of a paper birch and subalpine fir mixed-species stand in the sub-boreal spruce zone of British Columbia, For. Ecol. Manage. 130 (2000) 17-26.

[41] Woods K.D., Feiveson A.H., Botkin D.B., Statistical analysis for biomass density and leaf-area index estimation, Can. J. For. Res. 21 (1991) 974-989. 